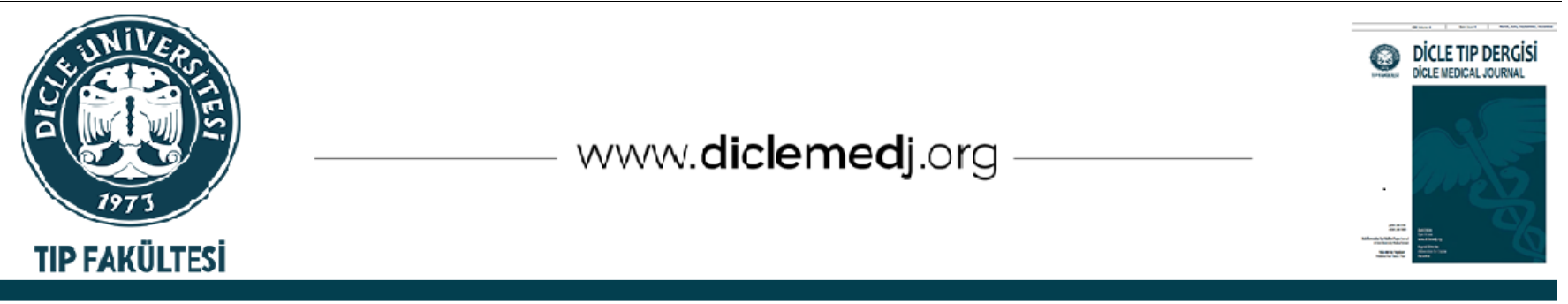

Özgün Araştırma / Original Article

\title{
Ratlarda Rottlerin'in Otofaji Üzerine Etkili Doz Düzeyinin Araştırılması
}

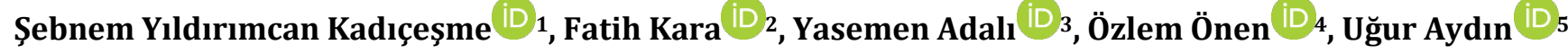 \\ 1 Kafkas Üniversitesi, Tıp Fakültesi, Tıbbi Biyoloji Ana Bilim Dalı, Kars, Türkiye \\ 2 Kafkas Üniversitesi, Tıp Fakültesi, Tıbbi Biyokimya Ana Bilim Dalı, Kars, Türkiye \\ 3 Çanakkale Onsekiz Mart Üniversitesi, Tıp Fakültesi, Tıbbi Patoloji Ana Bilim Dalı, Kars, Türkiye \\ 4 Kafkas Üniversitesi, Fen Edebiyat Fakültesi, Zooloji Ana Bilim Dalı, Kars, Türkiye \\ 5 Kafkas Üniversitesi, Veteriner Fakültesi, Veterinerlik Cerrahisi Ana Bilim Dalı, Kars, Türkiye
}

Geliş: 10.09.2020; Revizyon: 24.05.2021; Kabul Tarihi: 09.06.2021

Öz

Amaç: Otofaji, hücresel homeostazda rol oynayan fizyolojik bir süreçtir. Bununla birlikte, otofajik anomaliler kanser, nörodejeneratif hastalıklar ve kardiyovasküler hastalıklar gibi birçok patolojik durumla ilişkilidir. Rottlerin, otofajinin hastalıklarla ilişskisini değerlendirmek için kullanılabilecek ve tedavi stratejilerinde uygulanabilecek önemli bir otofaji aktivatörüdür. Ancak literatürde sıçanlarda otofajinin aktive edilmesinde bu molekülün dozları ile ilgili herhangi bir çalışma bulunmamaktadır. Bu çalışmanın amacı, Rottlerin'in sıçanlarda otofaji üzerindeki etkili doz düzeyinin araştırılmasıdır.

Yöntemler: Yirmi dört rat, her biri altı rat içeren dört gruba ayrıldı. Grup I'e (kontrol grubu) Rottlerin'in çözücüsü (DMSO) verildi. Grup II, III ve IV'e, sırasıyla, 0,5, 2 ve $4 \mathrm{mg} / \mathrm{kg}$ Rottlerin intraperitoneal olarak uygulandı. Ratların kalp dokuları otofajik vakuol, LC3B seviyeleri ve anti-LC3B boyanma paterni açısından incelendi. Ayrıca, kan örneklerinde LC3B seviyeleri ölçüldü.

Bulgular: Kalp dokularında otofajik vakuol, LC3B düzeyleri ve anti-LC3B boyanma paternleri açısından gruplar arasında anlamlı bir farklılık yoktu. Rottlerin dozu arttıkça, serum LC3B seviyelerinde artış eğilimi gözlendi; ancak, farklılıklar istatistiksel olarak anlamlı değildi.

Sonuçlar: Sonuç olarak, bu çalışmanın bulgularına göre, ratlarda Rottlerin kullanılarak kalp dokusunda otofajiyi aktive etmek için mevcut dozların ve/veya uygulama süresinin artırılması gerektiği görülmektedir. Bununla birlikte, serum sonuçları, farklı dokularda otofajik aktivitenin artmış olabileceğini göstermektedir.

Anahtar kelimeler: otofaji, Rottlerin, sıçan, LC3B, kalp.

DOI: $10.5798 /$ dicletip.988067

Correspondence / Yazışma Adresi: Fatih Kara, Kafkas Üniversitesi, Tıp Fakültesi, Tıbbi Biyokimya Ana Bilim Dalı, Kars, Türkiye e-mail: fatihkara65@hotmail.com 


\title{
Investigation of Effective Dose Level of Rottlerin on Autophagy in Rats
}

\begin{abstract}
Objective: Autophagy is a physiological process playing role in cellular homeostasis. However, autophagic anomalies are associated with many pathological conditions such as cancer, neurodegenerative diseases, and cardiovascular diseases. Rottlerin is an important autophagic activator, which may be used to evaluate the relationship of autophagy with diseases and may be applied in treatment strategies. Nevertheless, there are no studies in the literature regarding the doses of this molecule in activating autophagy in rats. The aim of this study is to investigate the effective dose level of Rottlerin on autophagy in rats.
\end{abstract}

Method: Twenty four rats were divided into 4 groups with 6 rats each. The solvent (DMSO) of the Rottlerin was given to Group I (control group). Group II, III, and IV were administered Rottlerin $(0.5,2$, and $4 \mathrm{mg} / \mathrm{kg}$ ) intraperitoneally, respectively. The heart tissues of rats were examined in terms of autophagic vacuole, LC3B levels, and anti-LC3B staining pattern. In addition, LC3B levels were measured in blood samples.

Results: There was no significant difference between the groups in terms of autophagic vacuole, LC3B levels, and anti-LC3B staining pattern in heart tissues. As the dose of the Rottlerin increased, a tendency to increase in serum LC3B levels was observed. However, the differences were not statistically significant.

Conclusion: In conclusion, according to our findings, it is seen that the dose and/or application time should be increased in order to activate autophagy in heart tissue by using Rottlerin in rats. However, serum results indicate that autophagic activity may be increased in different tissues.

Keywords: autophagy, Rottlerin, rat, LC3B, heart.

\section{GíRiş}

Otofaji, defektif organellerin ya da istenmeyen hücresel proteinlerin lizozomal yıkımını içeren intasellüler bir süreçtir ${ }^{1,2}$. Gelişmiş ökaryotlarda otofajinin üç farklı tipi vardır: mikrootofaji, şaperon aracılı otofaji, makrootofaji ${ }^{3}$. Memeli hücrelerinde bulunan en yaygin otofaji türü olan makrootofajide, sitoplazmik komponentlerin etrafi bir izolasyon membranı ile sarılır ve böylece lizozomla birleşecek şekilde bir otofagozom oluşturulur 3,4. Mikrootofajide, küçük kargolar direkt olarak lizozoma alınarak parçalanır ${ }^{3}$. Şaperon aracılı otofaji ise, şaperonlarla hedef proteinlerin lizozomlara sunulmasıdır ${ }^{3}$. Otofaji, hücresel homeostaziste görevli fizyolojik bir süreç olmakla birlikte, otofajik anomaliler; kanser, nörodejeneratif hastalıklar, kalp ve damar hastalıkları, enfeksiyon hastalıkları, kronik inflamatuvar hastalıklar, otoimmun hastalıklar, obezite, insülin direnci, tip 2 diyabet ve nonalkolik yağlı karaciğer hastalığı gibi birçok patolojik durumla da ilişkili olabilen önemli bir hücresel mekanizmadır ${ }^{4-6}$. Otofajik vakuoller, makrootofaji sürecinde ortaya çıkan bir dizi intrasellüler oluşumun (otofagozom, amfizom ve otolizozom) genel adı olarak kullanılmaktadır7. LC3 (microtubule-associated protein 1A/1B-light chain 3), normalde sitozolik alanda lokalize iken (LC3-I), otofajik süreçte fosfatidiletanolamin ile konjuge olarak (LC3-II) otofajik vakuol membranına dahil olmaktadır7. LC3 memelilerde birkaç homoloğa sahip olmakla birlikte, bunların arasında otofaji ölçümleri için en yaygın olarak kullanılanı LC3B'dir8. LC3B başlıca kalp, beyin, iskelet kası ve testiste eksprese edilir9,10. Ayrıca, LC3A'nın aksine, periferal kan lökositlerinde de bol miktarda eksprese edildiği gösterilmiştir ${ }^{9,10}$.

Günümüze kadar, çok sayıda otofaji aktivatörü ve inhibitörü tespit edilmiş olup; söz konusu bu ajanlar, hem otofaji ile hastalıklar arasındaki ilişkinin aydınlatılabilmesi amacıyla hem de otofaji ile ilişkili hastalıkların tedavisine yönelik yapılan birçok araştırmada kullanılmıștır ${ }^{5}$. Rottlerin, Mallotus philippinensis muell (Kamala) isimli küçük bir ağaç türünün olgun meyvelerinden elde edilen doğal bir polifenolik bileşik olup; PI3K/Akt/mTOR sinyal yolağını inhibe ederek otofajiyi aktive etmektedir ${ }^{11}$. 
Rottlerin, çeşitli hücre kültürleri üzerinde yapılan çalışmalarda bir otofaji aktivatörü olarak kullanılmıștır ${ }^{12-14}$. Chhiber ve ark.15,16 tarafından ratlarda yapılan çalışmalarda, oksalat ve kalsiyum oksalat aracil oksidatif hasar üzerine Rottlerinin etkisi değerlendirilmiş, ancak bu araştırmalarda Rottlerinin otofajik belirteçler üzerine etkisi incelenmemiștir. Tıbbi araștırmalarda, hastalık mekanizmalarının aydınlatılabilmesi ve yeni tedavi stratejilerinin geliştirilebilmesi için rat modelleri oldukça yaygın bir şekilde kullanılmaktadır ${ }^{17-19}$. Rottlerin, otofajinin hastalıklar ile ilişkisinin değerlendirilmesinde kullanılabilecek ve tedavi stratejilerinde uygulanabilecek önemli bir otofajik ajan olmakla birlikte, bu molekülün ratlarda hangi dozlarda otofajiyi aktive ettiğine dair literatürde herhangi bir çalışma bulunmamaktadır. $\mathrm{Bu}$ çalıșmanın amacı Rottlerinin otofaji üzerine etkili doz düzeyinin ratlarda araștırılmasıdır.

\section{YÖNTEMLER}

\section{Etik Onay}

Bu çalışmaya, üniversitemiz Hayvan Deneyleri Yerel Etik Kurulu'nun onayı ile başlanmıştır (2017-084).

\section{Deney Hayvanlarının Seçimi}

Bu çalışmada, 250-300 gram ağırlığında 24 adet erişkin Sprague-Dawley türü erkek rat kullanıldı. Ratlar 12 saat aydınlık 12 saat karanlık siklusunun olduğu 22- 25 0C'lik bir ortam sıcaklığına ve $\% 55 \pm \% 5^{\prime}$ lik nem oranına sahip bir odada polipropilen kafeslerde barındırıldı. Deney hayvanları randomize olarak 4 gruba ayrıldı:

Grup I (n=6): intraperitoneal (i.p.) olarak $\% 10$ 'luk 0,5 mL DMSO verilen kontrol grubu.

Grup II (n=6): Dimetilsülfoksitte (DMSO) çözünmüş $0,5 \mathrm{mg} / \mathrm{kg}$ Rottlerin'in i.p. olarak verildiği grup.
Grup III (n=6): DMSO'da çözünmüş $2 \mathrm{mg} / \mathrm{kg}$ Rottlerin'in i.p. olarak verildiği grup.

Grup IV ( $\mathrm{n}=6)$ : DMSO'da çözünmüş $4 \mathrm{mg} / \mathrm{kg}$ Rottlerin'in i.p. olarak verildiği grup.

Çalışmamızda kullanılan doz aralığı belirlenirken Chhiber ve ark.15,16 tarafindan yapılan çalışmalar temel alınmıştır.

\section{Rottlerin'in Hazırlanması}

Rottlerin'in (Sigma-Aldriche, ABD) DMSO'daki (Sigma-Aldriche, ABD) $30 \mathrm{mg} / \mathrm{mL}$ 'lik çözünürlüguü dikkate alınarak; Rottlerin dozları $\% 10^{\prime}$ luk $0,5 \mathrm{~mL}$ DMSO çözeltisinde $(50 \mu \mathrm{L}$ DMSO + $450 \mu \mathrm{L}$ serum fizyolojik) çözüldü.

\section{Doku ve Kan Numunelerinin Elde Edilmesi}

Çalışmada otofajik aktivitenin nispeten yüksek olması ve çalışma kolaylığından ötürü kalp dokusu tercih edildi ${ }^{20}$. Deney hayvanları, Rottlerin ve DMSO uygulamasının ardından 9 saat sonra inhalasyon yoluyla eter anestezisine alınarak; kan örnekleri intrakardiyak olarak elde edildi. Daha sonra servikal dislokasyon yöntemi ile ötenazileri gerçekleştirilen ratların kalp dokuları çıkarıldı.

\section{Dokuların Histopatolojik Açıdan İncelenmesi}

Diseksiyon ile alınan kalp dokuları \%10'luk tamponlu formaldehitte 48 saat bekletildikten sonra kasetlenerek otomatize cihazda (TissueTek Vip6, Sakura Finetek, Japonya) doku takibine alındı. Doku takip işlemi sonrasında usulüne uygun olarak parafine gömülen dokulardan elde edilen bloklar mikrotom (ACCU-Cut SRM200, Sakura Finetek, Japonya) ile kesilerek 4 mikron kalınlığında kesitler elde edildi. Kesitler etüvde deparafinize edildikten sonra otomatize cihazda (ST5010 XL Autostainer, Leica Microsystems, ABD) Hematoksilen\&Eozin (H\&E) ile boyandı. Boyama işlemi sonrasında manuel olarak entellan ile kapatılan kesitler ışı mikroskobu (BX46, Olympus, Japan) ile değerlendirildi. 
Değerlendirmede otofajik vakuollerin varlığg 0 (yok) ve 1 (var) olarak skorlandı.

\section{İmmunohistokimyasal Boyama ve İnceleme}

Hazırlanan parafin bloklardan 3 mikron kalınlığında kesitler pozitif şarjlı polilizinli lam üzerine alındı. Ardından 80 0C'de 1 saat süreyle etüvde bekletilen preparatlar, önce 5 dakika süre ile dilüsyonu azalan ksilen serisinden, daha sonra distile sudan geçirildi. 1:10 oranında sulandırılan sitrat tamponu ile antijen retrieval işlemi yapıldı. Sonrasında distile su ile yıkanan kesitler, \%3'lük hidrojen peroksit içinde 10 dakika süreyle bekletilip distile su ile yıkandı. $\mathrm{Bu}$ işlemden sonra, fosfat tamponlu (PBS) solüsyonda bekletilen primer antikor (antiLC3B antibody ab63817, Abcam) preparatlara uygulandı ve tekrar PBS ile yıkama işlemi yapıldı. Daha sonra biotin ve streptavidin uygulamaları gerçekleştirildi (UltraVision Large Volume Detection System anti-Polyvalent, HRP Thermo Scientific, ABD). Ardından kromojende (UltraVision Quanto Detection System DAB, Thermo Scientific, ABD), entellan kullanılarak lamel ile kapatıldı. Kesitler ışık mikroskobu (BX46, Olympus, Japonya) ile değerlendirildi ve boyanma özelliği 0 (boyanma yok) ve 1 (boyanma var) şeklinde skorlandı.

\section{Biyokimyasal Ölçümler}

Kalp dokusu örnekleri PBS ( $\mathrm{pH}=7,4 ; \mathrm{M}=50 \mathrm{mM}$ ) ile yıkandı ve daha sonra ağırlıkları tartıldı. 100 mg kalp dokusu üzerine $1 \mathrm{~mL}$ PBS ilave edilerek doku numuneleri homojenize edildi (WiseTis Homogenizer, Daihan Scientific, Kore). Homojenizasyonun ardından 3000 rpm'de 20 dakika süreyle santrifüj edilen numunelerin süpernatan kısımları alikotlandı. Analiz zamanına kadar örnekler -20 oC'de muhafaza edildi.

Oda sıcaklığında 20 dakika süreyle pıhtılaşması için bekletilen kan örnekleri, 3000 rpm'de 20

dakika süreyle santrifüj edilerek serumlar ayrıştırıldı.
Elde edilen serum ve doku örneklerinde LC3B düzeyleri "Rat (MAP1LC3B) ELISA kiti (SunRed, Çin, Katalog No: SRB-T-80462)" kullanılarak sandwich ELISA yöntemi ile ölçüldü.

\section{İstatistiksel Analiz}

Elde edilen veriler SPSS 20 (IBM, ABD) istatistik programı ile değerlendirildi. Gruplardaki verilerin normal dağılıp dağılmadığı Kolmogorov-Smirnov testi ile analiz edildi. Doku ve kan örneklerinde, çalışma grupları arasında LC3B düzeyleri açısından bir farklılık olup olmadığı One-Way ANOVA testi ile değerlendirildi. Gruplar otofajik vakuol ve immunohistokimyasal boyanma skoru açısından Mann-Whitney $U$ testi ile karşılaştırıldı. $\quad \mathrm{p}<0.05$ istatistiksel olarak anlamlı kabul edildi.

\section{BULGULAR}

Biyokimyasal ölçüm sonucunda, kalp dokularında ve serum örneklerinde LC3B seviyeleri açısından anlamlı bir farklılık bulunamadı (sırasıyla, $p=0,176$ ve $p=0,231$ ) (Tablo 1). Bununla birlikte, istatistiksel açıdan anlamlı olmamasına rağmen, serum örneklerinde doza bağlı olarak LC3B seviyelerindeki artış trendi dikkat çekiciydi (Şekil 1). Grup I ve Grup III'te herhangi bir otofajik vakuol gözlenmedi (Resim 1). Grup II ve Grup IV'te otofajik vakuol bulunan birer rat saptandı (Resim 2). Gruplar arasında otofajik vakuol skorları açısından istatistiksel olarak anlamlı bir farklılık yoktu (Tablo 2). Anti-LC3B antikoru ile yapılan immunohistokimyasal boyalı kesitlerin değerlendirilmesinde, tüm ratlarda izlenen tablo benzer nitelikte olup yaygin ve hafif karakterde sitoplazmik boyanma paterni şeklindedir (Resim 3). Bu nedenle antiLC3B antikoru ile izlenen bu bulgular nonspesifik boyanma olarak kabul edilmiștir. 
Tablo I: Deney gruplarında LC3B düzeyleri (ng/mL).

\begin{tabular}{|ccc|}
\hline & $\begin{array}{c}\text { Kalp Dokusu } \\
\text { (mean } \pm \text { SD) }\end{array}$ & $\begin{array}{c}\text { Serum } \\
\text { (mean } \pm \text { SD) }\end{array}$ \\
\hline Grup I (DMSO) & $18,81 \pm 1,20$ & $3,36 \pm 4,33$ \\
Grup II (0,5 mg/kg & $16,70 \pm 1,53$ & $4,82 \pm 0,56$ \\
Rottlerin) & & \\
Grup III (2 mg/kg & $18,13 \pm 1,68$ & $7,22 \pm 0,38$ \\
Rottlerin) & & \\
Grup IV (4 mg/kg & $17,95 \pm 1,88$ & $8,44 \pm 0,24$ \\
Rottlerin) & & 0,231 \\
p değeri & 0,176 & \\
\hline
\end{tabular}

Tablo II: Grupların otofajik vakuol skoru açısından karşılaştırılması.

\begin{tabular}{|ccccc|}
\hline & Grup I & Grup II & Grup III & Grup IV \\
\hline Grup I & - & $0,273^{*}$ & 1,000 & 0,317 \\
Grup II & - & - & 0,371 & 0,389 \\
Grup III & - & - & - & 0,361 \\
\hline
\end{tabular}

*Mann-Whitney U testine göre $p$ değerleri.

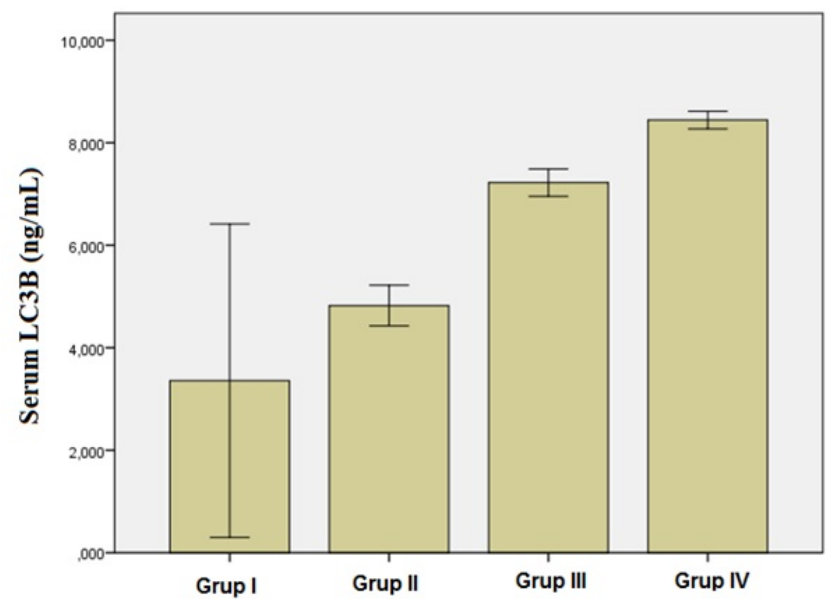

Şekil 1. Deney gruplarında LC3B düzeyleri (ng/mL). Grup I: DMSO; Grup II: $0,5 \mathrm{mg} / \mathrm{kg}$ Rottlerin; Grup III: $2 \mathrm{mg} / \mathrm{kg}$ Rottlerin; Grup IV; 4 mg/kg Rottlerin.

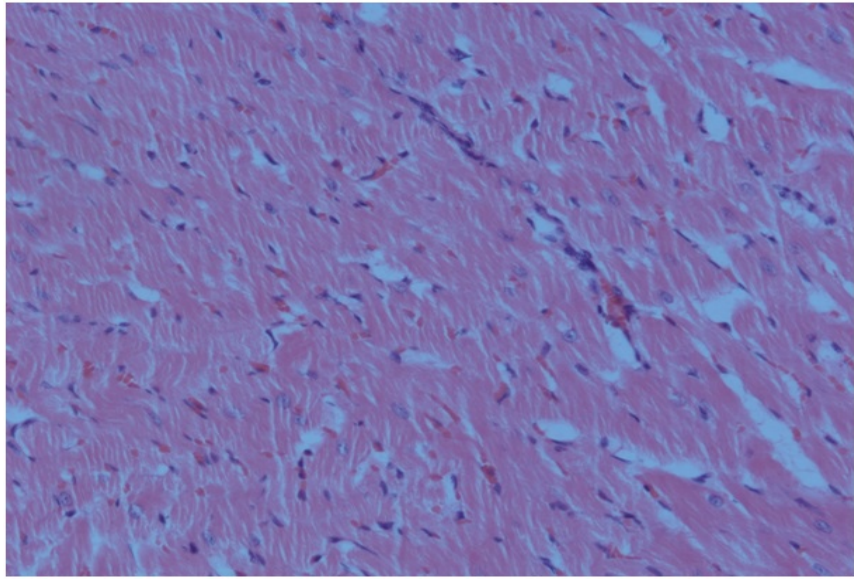

Resim 1. Grup III'e ait morfolojik limitlerde kalp dokusu (H\&E, 200x).

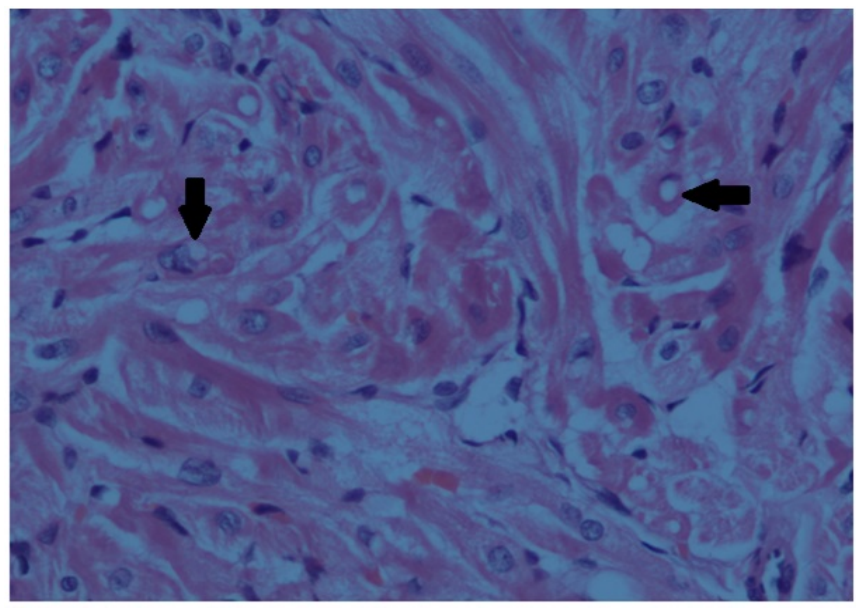

Resim 2. Grup IV'e ait kesitte otofajik vakuoller (siyah oklar) (H\&E, 400x).

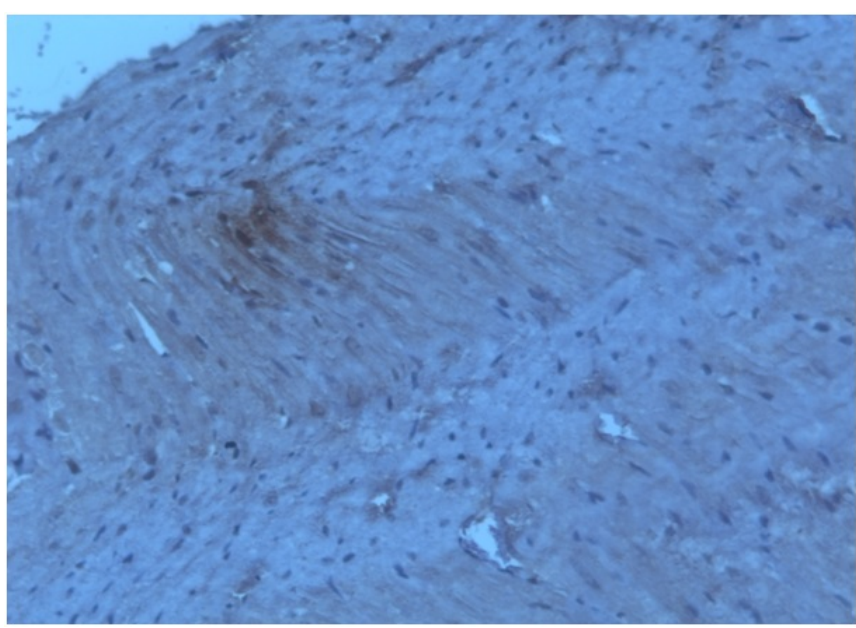

Resim 3. Grup IV'e ait kesitte anti-LC3B ile immunohistokimyasal boyanma (200x). 


\section{TARTIŞMA}

Protein kinaz C (PKC) inhibitörü olarak bilinen ve doğal bir polifenolik bileşik olan Rottlerin, antioksidan, apoptotik, antiinflamatuvar, antiproliferatif, antianjiyogenik, antiamiloid, antikanserojen, antiallerjik, antimikrobiyal, antifungal ve antiparazitik özelliklerinden dolayı çok sayıda bilimsel araştırmaya konu olmuştur ${ }^{21,22}$. Rottlerinin önemli bir diğer etkisi de, PI3K/Akt/mTOR sinyal yolağını inhibe ederek otofajiyi aktive etmesidir ${ }^{11}$. Rottlerinin otofaji üzerindeki etkisi, birçok hücre kültürü çalışmasında değerlendirilmiştir ${ }^{12-14}$. Bununla birlikte, yaptığımı araştırmada deney hayvanlarına doğrudan Rottlerin uygulanarak otofajik etkilerin incelendiği bir çalışmaya rastlamadık. Bizim çalışmamız, ratlarda farklı dozlarda Rottlerin'in otofaji üzerine etkisinin değerlendirildiği ilk çalışmadır.

Bu çalışmada, her ne kadar farklılık istatistiksel açıdan anlamlı olmasa da, Rottlerin dozu arttıkça serum örneklerinde LC3B seviyelerinin de artma eğiliminde olduğu görüldü. Cheng ve ark. $^{23}$ sepsisin indüklediği miyokart infarktüsü olan hastalarda baskılanmış otofajik aktivitenin bir sonucu olarak serum LC3B düzeylerinin azaldığını bulmuşlardır. Bu sonuç, serum LC3B düzeylerinin lokal otofajik değişiklikleri yansıtabileceğini göstermektedir. Li ve ark. ${ }^{24} \mathrm{da}$ akut iskemik stroklu hastalarda serum LC3B düzeylerinin arttığını ve infarkt hacmi ile korele olduğunu tespit etmişlerdir. Bununla birlikte söz konusu çalıșmada serum LC3B düzeyleri ile nörolojik defisitin şiddeti arasında bir ilişki belirlenememiş ve bu durum, vücuttaki diğer organların da, serumdaki otofajik belirteçler üzerindeki etkisine bağlanmıştır. Dolayısıyla, bizim çalışmamızda tespit ettiğimiz, Rottlerin dozuna bağlı serum LC3B seviyelerindeki artma eğilimi, organizmada lokal bir otofajik aktivite artışına işaret etmektedir. Bu çalışmada, kalp dokusunda otofajik vakuol, LC3B seviyeleri ve anti-LC3B ile boyanma paternleri açısından gruplar arasında anlamlı bir farklılık gözlenmemesi; söz konusu muhtemel otofajik aktivite artışının kalp dışı bir dokudan kaynaklanabileceğini düşündürmektedir.

Sonuç olarak, elde ettiğimiz bulgulara göre, ratlarda Rottlerin kullanarak kalp dokusunda otofajiyi aktive etmek için doz ve/veya uygulama süresinin artırılması gerektiği görülmektedir. Bununla birlikte serum sonuçları, farklı dokularda otofajik aktivitenin artmış olabileceğine işaret etmektedir.

Etik Kurul Kararı: Bu çalışmaya, üniversitemiz Hayvan Deneyleri Yerel Etik Kurulu'nun onayı ile başlanmıştır (2017-084).

Çıkar Çatışması Beyanı: Çıkar çatışması bulunmamaktadir.

Finansal Destek: $\mathrm{Bu}$ çalışma Kafkas Üniversitesi Bilimsel Araştırma Projeleri Koordinatörlüğü tarafından desteklenmiştir (2018-TS-51).

Declaration of Conflicting Interests: The author declare that she has no conflict of interest.

Financial Disclosure: This study was funded by the Scientific Research Projects Committee of Kafkas University (2018-TS-51).

\section{KAYNAKLAR}

1. Al-Bari MAA, Xu P. Molecular regulation of autophagy machinery by mTOR-dependent and independent pathways. Ann N Y Acad Sci. 2020; 1467: 3-20.

2. Karadağ A. Otofaji: programlı hücre ölümü. ASHD. 2016; 15: 19-26.

3. Allen EA, Baehrecke EH. Autophagy in animal development. Cell Death Differ. 2020; 27: 903-18.

4. Menikdiwela KR, Ramalingam L, Rasha F, et al. Autophagy in metabolic syndrome: breaking the wheel by targeting the renin-angiotensin system. Cell Death Dis. 2020; 11: 87.

5. Morel E, Mehrpour M, Botti J, et al. Autophagy: a druggable process. Annu Rev Pharmacol Toxicol. 2017; 57: 375-98. 
6. Akkoc Y, Gozuacik D. MicroRNAs as major regulators of the autophagy pathway. Biochim Biophys Acta Mol Cell Res. 2020; 1867: 118662.

7. Klionsky DJ, Abdalla FC, Abeliovich $\mathrm{H}$, et al. Guidelines for the use and interpretation of assays for monitoring autophagy (3rd edition). Autophagy. 2016; 12: 1-222.

8. Mizushima N, Yoshimori T. How to interpret LC3 immunoblotting. Autophagy. 2007; 3: 542-5.

9. He H, Dang Y, Dai F, et al. Post-translational modifications of three members of the human MAP1LC3 family and detection of a novel type of modification for MAP1LC3B. J Biol Chem. 2003; 278: 29278-87.

10. Zois CE, Giatromanolaki A, Sivridis E, et al. "Autophagic flux" in normal mouse tissues: focus on endogenous LC3A processing. Autophagy. 2011; 7: 1371-8.

11. Ma J, Hou Y, Xia J, Zhu X, Wang ZP. Tumor suppressive role of rottlerin in cancer therapy. Am J Transl Res. 2018; 10: 3345-56.

12. Kumar D, Shankar S, Srivastava RK. Rottlerin induces autophagy and apoptosis in prostate cancer stem cells via PI3K/Akt/mTOR signaling pathway. Cancer Lett. 2014; 343: 179-89.

13. Song J, Zhou Y, Gong Y, Liu H, Tang L. Rottlerin promotes autophagy and apoptosis in gastric cancer cell lines. Mol Med Rep. 2018; 18: 2905-13.

14. Qomaladewi NP, Kim MY, Cho JY. Rottlerin reduces cAMP/CREB-mediated melanogenesis via regulation of autophagy. Int J Mol Sci. 2019; 20: E2081.

15. Chhiber N, Kaur T, Singla S. Rottlerin, a polyphenolic compound from the fruits of Mallotus phillipensis (Lam.) Müll. Arg., impedes oxalate/calcium oxalate induced pathways of oxidative stress in male wistar rats. Phytomedicine. 2016; 23: 989-97.
16. Chhiber N, Kaur T, Singla S. Salubrious effect of rottlerin on hyperoxaluria induced oxidative damage in rats. Int J Pharm Pharm Sci. 2016; 8: 138.

17. Dokumacıoğlu E, Iskender H, Aktas MS, et al. The effect of sulforaphane on the levels of serum cystatin-c in acetaminophen-induced nephrotoxicity in rats. Dicle Med J. 2016; 43: 383-9.

18. Gedikli S, Şengül E. The effects of quercetin on cyclophosphamide induced hepatotoxicity in the rats. Dicle Med J. 2019; 46: 41-50.

19. Solak T, Salihoğlu YS, Erdemir RU. Evaluation of the effect of agmatine with Tc- $99 \mathrm{~m}$ pertechnetate scintigraphy in experimental testicular torsiondetorsion. Dicle Med J. 2020; 47: 387-93.

20. Buckley KM, Hess DL, Sazonova IY, et al. Rapamycin up-regulation of autophagy reduces infarct size and improves outcomes in both permanent MCAL, and embolic MCAO, murine models of stroke. Exp Transl Stroke Med. 2014; 6: 8.

21. Maioli E, Torricelli C, Valacchi G. Rottlerin and curcumin: a comparative analysis. Ann N Y Acad Sci. 2012; 1259: 65-76.

22. Maioli E, Daveri E, Maellaro E, et al. Nonconventional rottlerin anticancer properties. Arch Biochem Biophys. 2018; 645: 50-3.

23. Cheng Mm W, Long $\mathrm{Y}$, Wang $\mathrm{H}$, et al. Role of the mTOR signalling pathway in human sepsis-induced myocardial dysfunction. Can J Cardiol. 2019; 35: 875-83.

24. Li H, Qiu S, Li X, Li M, Peng Y. Autophagy biomarkers in CSF correlates with infarct size, clinical severity and neurological outcome in AIS patients. J Transl Med. 2015; 13: 359. 